\title{
Analisis Kebutuhan Mahasiswa terhadap Bahan Ajar Perkuliahan Proposal dan Tata Tulis Ilmiah
}

\author{
Sri Nur Yuliyawati \\ Politeknik Negeri Bandung, Desa Cowaruga, Kabupaten Bandung Barat 40559 \\ Correspondence email: srinuryuli@polban.ac.id
}

\begin{abstract}
Abstrak. Pokok bahasan dan subpokok bahasan bahan ajar perkuliahan "Proposal dan Tata Tulis Laporan" pada Program Studi Teknik Perwatan dan Perbaikan Gedung belum dibuat berdasarkan analisis kebutuhan mahasiswa. Padahal, bahan ajar merupakan komponen penting yang diperlukan dalam proses pembelajaran. Untuk itu, dilakukan penelitian yang bertujuan mendeskripsikan Capaian Pembelajaran yang sekait dengan mata kuliah serta memetakan kebutuhan mahasiswa terhadap pokok bahasan dan subpokok bahasan bahan ajar mata kuliah Proposal dan Tata Tulis Laporan. Dalam penelitian ini digunakan metode deskriptif dengan sumber data dokumen Kurikulum 2016 dan nara sumber 32 mahasiswa. Hasil penelitian ini adalah terdapat enam Capaian Pembelajaran yang sekait dengan perkuliahan Proposal dan Tata Tulis Laporan dan terdapat tujuh pokok bahasan yang dibutuhkan mahasiswa yaitu "Proposal, Penulisan Laporan Ilmiah, konvensi Naskah, Plagiarisme dan Pengutipan, Peristilahan ilmiah, Kalimat Ilmiah, serta Presentasi Ilmiah". Simpulan penelitian ini adalah pokok bahasan dan subpokok bahasan yang dibutuhkan mahasiswa pada perkuliahan Proposal dan Tata Tulis Laporan relevan dengan keenam Capaian Pembelajaran sehingga dapat dijadikan bahan ajar.
\end{abstract}

Kata kunci: analisis kebutuhan; bahan ajar

Abstract. The topics and sub-topics of teaching materials in "Proposal and Tata Tulis Laporan" courses in Building Design Engineering Study Program have not been developed based on the students' need analysis, whereas teaching materials are essential components in a learning process. For this reason, this study was conducted to describe learning outcomes which are relevant to the courses and to map the students' needs of the topics and sub-topics of "Proposal and Tata Laporan" courses. In this study, a descriptive method was used with the 2016 Curriculum document as a data source and 32 students as participants. The results of this study are six learning outcomes which are relevant to the "Proposal dan Tata Tulis Laporan" courses and seven topics needed by the students; Proposal, Penulisan Laporan Ilmiah, konvensi Naskah, Plagiarisme dan Pengutipan, Peristilahan ilmiah, Kalimat Ilmiah, serta Presentasi Ilmiah. This study concludes that these topics and sub-topics needed by the students are relevant to the six learning outcomes so that those topics and sub-topics can be used as teaching materials.

Keywords: need analysis; teaching materials

\section{PENDAHULUAN}

Mata kuliah PRTTI (Proposal dan Tata Tulis Ilmiah) merupakan mata kuliah yang harus ditempuh oleh setiap mahasiswa Program Studi TPPG (Program Studi Teknik Perawatan dan Perbaikan Gedung) Politeknik Negeri Bandung. Mata kuliah ini baru diberlakukan pada Kurikulum Program Studi TPPG tahun 2016 dan dialokasikan pelaksanaannya pada semester 6 . Artinya, pada semester genap tahun 2020 ini, mata kuliah PRTTI baru dilaksanakan untuk kedua kalinya di Prodi TPPG.

Perkuliahan PRTTI masih terkendala oleh beberapa hal, satu di antaranya adalah bahan ajar. Padahal, bahan ajar merupakan komponen penting yang diperlukan dalam proses pembelajaran. Dengan adanya bahan ajar yang sesuai kebutuhan/harapan mahasiswa, dapat membantu kelancaran kegiatan pembelajaran (Irawati dan Saifuddin, 2018). Bahan ajar harus disusun berdasarkan kurikulum dan kebutuhan mahasiswa sehingga mahasiswa termotivasi mengikutinya. Hal ini pararel dengan "prinsip pembelajaran orang dewasa (andragogi) bahwa seseorang akan mau belajar dan memperoleh pengetahuan apabila sesuai dengan kebutuhannya. Oleh sebab itu, bahan ajar merupakan indikator penting yang akan menentukan tercapai atau tidaknya tujuan pembelajaran" (Alfiriani, Hutabri, dan Pratama, 2017).

Agar bahan ajar perkuliahan PRTTI tepat, diperlukan masukan pokok bahasan dan subpokok bahasan yang menjadi kebutuhan mahasiswa sebagai peserta didik. Dengan masukan dari mahasiswa, dosen dapat mengembangkan bahan ajar menjadi lebih tepat dan sesuai. Untuk mendapatkan masukan dari mahasiswa, dilakukan analisis kebutuhan. Salah satu asumsi dasar pengembangan kurikulum dalam bidang pendidikan, harus didasarkan pada analisis kebutuhan mahasiswa. Metode analisis kebutuhan dibuat untuk bisa mengukur tingkat kesenjangan yang terjadi dalam pembelajaran mahasiswa dari apa yang diharapkan dan apa yang sudah didapat, (Nurjannah 2018). Tujuan utama analisis kebutuhan adalah untuk mengetahui perubahan-perubahan yang perlu dilakukan dalam upaya memperbaiki kurikulum yang berhubungan dengan konten yang spesifik (Al-hamlan dan Baniabdelrahman 2015). 
Berdasarkan uraian tersebut, permasalahan penelitian ini adalah pokok bahasan dan subpokok bahasan bahan ajar mata kuliah PRTTI belum dibuat berdasarkan analisis kebutuhan mahasiswa. Permasalahan tersebut dirumuskan dalam pertanyaan penelitian berikut ini.

(1) CP apa yang terdapat dalam Kurikulum Prodi TPPG yang sekait dengan mata kuliah PRTTI?

(2) Bagaimana peta kebutuhan mahasiswa prodi TPPG terhadap pokok bahasan dan subpokok bahasan bahan ajar mata kuliah PRTTI?

Berdasarkan pertanyaan penelitian tersebut, tujuan penelitian ini adalah mendeskripsikan CP yang sekait dengan mata kuliah PRTTI pada kurikulum prodi TPPG serta memetakan kebutuhan mahasiswa prodi TPPG terhadap pokok bahasan dan subpokok bahasan bahan ajar mata kuliah PRTTI.

\section{Kajian Pustaka \\ Analisis Kebutuhan (Self Assement)}

Tantangan pendidikan tinggi saat ini tidak dapat ditanggulangi dengan paradigma lama, tetapi diperlukan inovasi yang dapat mengembangkan segala dimensi yang ada pada mahasiswa. Penanggulangan tantangan pendidikan tinggi dapat dilakukan dengan mengembangkan analisis kebutuhan mahasiswa dan mengikutsertakan peran mahasiswa karena strategi belajar dianggap lebih penting daripada strategi mengajar. Dengan demikian, mahasiswa dilatih menggunakan strategi belajar dan dilatih meningkatkan keberhasilan belajarnya secara mandiri.

Dalam pendidikan vokasi, proses interaksi mahasiswa dengan dosen dan sumber belajar pada suatu lingkungan belajar disiapkan untuk pekerjaan dan keahlian terapan tertentu. Oleh karena itu, pembelajaran mengarah pada pendidikan terapan yang mendukung konpetensi lulusan sehingga setiap pembelajaran lebih bersifat pembimbingan (Isgandhi 2020). Hal tersebut menyebabkan mahasiswa vokasi harus selalu termotivasi dan berperan serta dalam perkuliahan. Untuk itu, harapannya/kebutuhan mahasiswa perlu terakomodasi dalam perumusan bahan ajar. Sejalan dengan pendapat Isgandhi (2020), Thamrin (2014) mengemukakan mahasiswa pada pendidikan vokasional merupakan bagian dari pendidikan kecakapan hidup harus belajar untuk bisa karena ciri khas pendidikan vokasional adalah belajar untuk bisa.

Agar kebutuhannya mahasiswa dapat terakomodasi dalam perkuliahan, perlu dilakukan analisis kebutuhan mahasiswa. Analisis kebutuhan memiliki peranan vital dalam membantu proses pembelajaran. Analisis kebutuhan merupakan prinsip mendasar dalam sistem pembelajaran bahasa yang terpusat (Ndukwe, 2015). Dalam mengevaluasi aktivitas pendidikan, para peneliti dan dosen perlu melakukan analisis kebutuhan. Definisi lain tentang analisis kebutuhan adalah sebuah proses bertahap untuk memperoleh informasi mengenai kebutuhan mahasiswa, referensi awal, dan masalah yang diidentifikasi oleh pendapat secara subjektif (mahasiswa) dan objektif (desainer, dosen, lulusan) sesuai dengan kebutuhan untuk mahasiswa (Andi dan Arafah, 2017). Nurhayati (2012) menyatakan bahwa analisis kebutuhan merupakan suatu proses awal yang dilakukan untuk menyusun bahan ajar yang sesuai dengan kebutuhan siswa. Analisis kebutuhan merupakan cara atau metode yang digunakan dalam menentukan perbedaan antara kenyataan dan keinginan (Puspita et al. 2017). Tujuan utama analisis kebutuhan adalah untuk mengetahui perubahan-perubahan yang perlu dilakukan dalam upaya memperbaiki kurikulum yang berhubungan dengan konten yang spesifik (Al-hamlan dan Baniabdelrahman 2015; Helaluddin 2018).

Dalam analisis kebutuhan dapat digunakan prosedur kuesioner, self-rating, wawancara, meeting, observasi atau pengamatan, mengumpulkan sampel, analisis tugas, studi kasus, dan analisis informasi yang ada. Selain prosedur, hal lain yang harus dipertimbangkan dalam melakukan analisis kebutuhan adalah prinsip-prinsip dalam pengembangannya. Prinsip tersebut merupakan kaidah yang akan menjiwai pelaksanaannya. Prinsip-prinsip tersebut adalah ilmiah, relevan, sistematis, konsisten, memadai, aktual atau kontekstual, fleksibel, dan menyeluruh (Helaluddin, 2018).

Analisis kebutuhan banyak digunakan dalam pelitian pengembangan bahan ajar seperti yang dilakukan Irawati dan Saifuddin (2018) yang menyimpulkan bahwa pada pembelajaran mata kuliah pengantar profesi guru biologi terdapat kendala, yaitu tidak adanya bahan ajar berupa buku ajar yang bisa dijadikan sebagai pedoman dalam proses pembelajaran,. Selain itu, penelitian analisis kebutuhan tentang bahan ajar dilakukan pula oleh Kurniawan et al. (2018) dengan simpulan "Hasil analisis angket kebutuhan terhadap pengembangan bahan ajar menunjukkan bahwa mahasiswa membutuhkan bahan ajar yang mampu menjelaskan materi pembelajaran secara rinci, dilengkapi dengan penurunan rumus dan visualisai konten pembelajaran yang bersifat abstrak". Penelitian analisis kebutuhan pada bahan ajar, telah dilakukan pula oleh (Yusuf, 2014);(Alfiriani et al., 2017) dan(Nurjannah, 2018).

\section{Bahan Ajar}

Bahan ajar adalah sumber belajar yang berperan sangat penting untuk menunjang proses pembelajaran. Bahan ajar diperlukan sebagai pedoman beraktivitas dalam proses perkuliahan. Hal ini sejalan dengan hasil penelitian Irawati dan Saifuddin (2018) bahwa kendala yang dihadapi pada pembelajaran mata kuliah adalah belum adanya bahan ajar yang bisa dijadikan sebagai pegangan dalam proses pembelajaran.

Bahan ajar dapat dijadikan salah satu usaha untuk meningkatkan prestasi belajar mahasiswa. Selain itu, kehadiran bahan ajar dapat digunakan sebagai media 
memperlakuan mahasiswa secara individual sesuai dengan karakteristik, menangani persoalan rendahnya aktualisasi diri mahasiswa, sehingga materi-materi yang kurang dipahami dapat dieksplorasi kembali melalui bahan ajar (Lestari 2013). Sejalan dengan pendapat tersebut,Yuliyawati (2016) menjelaskan bahwa keberhasilan sebuah prosesbelajar mengajar tidaklah semata-mata ditentukan oleh fasilitas yang canggih dan memadai, pengajar yang andal danberpengalaman, tetapi oleh difungsikannya secara optimal semua komponen pendukung, satu di antaranya adalah bahan ajar.

Bahan ajar diklasifikasikan dalam tiga bidang, yaitu pengetahuan (fakta, konsep, prinsip, dan prosedur) keterampilan, dan afektif. Berdasarkan klasifikasi itulah, dipilih bahan yang akan disajikan dalam perencanaan untuk mencapai tujuan pembelajaran yang telah dirumuskan sebelumnya. Bahan ajar harus memenuhi tiga prinsip, yaitu prinsip relevansi, artinya materi pembelajaran hendaknya relevan atau ada keterkaitannya dengan $\mathrm{CP}$; kedua, prinsip konsistensi artinya keajegan; ketiga, prinsip kecukupan artinya materi yang diajarkan tidak boleh terlalu sedikit, dan tidak boleh terlalu banyak. Cukup tidaknya aspek materi dari suatu materi pembelajaran akan sangat membantu tercapainya $\mathrm{CP}$ yang telah ditentukan. Jika terlalu sedikit akan kurang membantu mencapai standar kompetensi dan kompetensi dasar. Hal ini menyebabkan mau tidak mau dosen harus selalu menyesuaikan dan mengkolaborasikan bahan ajar serta materi perkuliahan dengan perubahan kurikulum tersebut, (Suhardiyanto 2018). Selain itu, Bahan ajar harus menumbuhkan motivasi/minat mahasiswa, aktual, menarik, jelas, sistematis, praktis (Prastowo, 2012). Dengan demikian, perumusan pokok bahasan dan subpokok bahasan bahan ajar berdasarkan analaisis kebutuhan mahasiswa yang dilakukan pada penelitian ini, sejalan dengan pendapat-pendapat tersebut.

\section{METODE}

Sesuai dengan topik dan rumusan masalah, dalam penelitian ini digunakan metode deskriptif. Penggunaan metode deskriptif penulis pandang relevan karena penelitian ini bertujuan memberikan deskripsi mengenai hasil pengkajian pada masalah yang diteliti. Sumber data penelitian ini adalah dokumen Kurikulum Program Studi TPPG Tahun 2016 dan nara sumber, yaitu mahasiswa Program Studi TPPG yang telah mengajukan proposal TA (Tugas Akhir) atau sedang menyelesaikan TA.

\section{Alur Penelitian}

Penelitian ini diawali dengan kajian pustaka tentang teori bahan ajar dan analisis kebutuhan. Langkah berikutnya adalah pembuatan instrumen kesatu berupa pedoman analisis dokumen kurikulum untuk memperoleh $\mathrm{CP}$ yang berkaitan dengan mata kuliah PRTTI dan pembuatan instrumen kedua berupa kuesioner untuk memperoleh kebutuhan mahasiswa terhadap pokok bahasan dan subpokok bahasan bahan ajar perkuliahan PRTTI. Kemudian, dilakukan penganalisisan dokumen Kurikulum Program Studi TPPG Tahun 2016 dan penyebaran kuesioner tentang analisis kebutuhan pokok bahasan dan subpokok bahasan mata kuliah PRTTI kepada mahasiswa tinkat 3 dan 4 TPPG dilanjutkan dengan pendeskripsian $\mathrm{CP}$ yang berkaitan dengan mata kuliah PRTTI, penganalisisan, dan pendeskripsian kuesioner terisi tentang kebutuhan mahasiswa terhadap pokok bahasan dan subpokok bahasan bahan ajar perkuliahan PRTTI. Berdasarkan pendeskripsian $\mathrm{CP}$ dan pendeskripsian kuesioner terisi, dibuat peta kebutuhan mahasiswa akan pokok bahasan dan subpokok bahasan bahan ajar perkuliahan PRTTI. Penelitian ini akan diakhiri dengan pembuatan laporan. Secara visual alur penelitian tersebut dapat disimak pada gambar berikut ini.

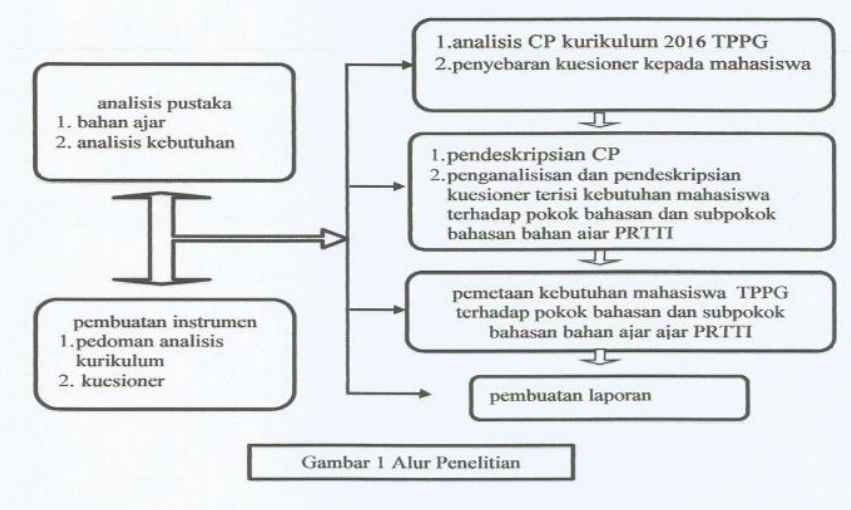

\section{Sumber Data, Teknik Pengumpulan Data}

Data penelitian ini adalah dokumen Kurikulum Program Studi TPGG Tahun 2016 dan nara sumber yaitu mahasiswa tingkat 3 dan 4 TPGG. Ditentukannya mahasiswa tingkat 3dan 4 sebagai narasumber karena mereka telah menyelesaikan perkuliahan PRTTI, telah membuat proposal PKL/TA dan sedang menyelesaikan penulisan laporan PKL/TA yang sangat terkait dengan pengimplementasian perkuliahan PRTTI sehingga diharapkan memahami kebutuhan bahan ajar perkuliahan PRTTI.

\section{Instrumen Penelitian}

Pembuatan instrumen penelitian ini bertujuan mendapatkan data yang relevan dan menyamakan titik pandang antara penulis dengan pihak-pihak yang berkepentingan dengan penelitian ini. Instrumeninstrumen penelitian ini dirumuskan untuk mendeskripsikan CP (capaian pembelajaran) pada kurikulum TPPG yang sekait dengan perkuliahan PRTT serta memetakan kebutuhan mahasiswa akan pokok bahasan dan subpokok bahasan bahan ajar PRTTI.

Instrumen untuk mendeskripsikan $\mathrm{CP}$ pada kurikulum TPPG dan CP mata kuliah PRTT Program Studi TPPG berupa pedoman pertanyaan yang akan digunakan oleh peneliti untuk menganalisis kurikulum Program Studi TPPG. Instrumen untuk memetakan kebutuhan mahasiswa akan pokok bahasan dan 
subpokok bahasan bahan ajar PRTTI berupa kuesioner yang disebarkan secara daring. Pada kuesioner tersebut, responden diminta menentukan kebutuhannya dengan cara menceklis satu di antara lima opsi/pernyataan, yaitu: 1 sangat penting, 2 penting, 3 cukup penting, 4 kurang pentin, dan 5 tidak penting pada setiap pokok bahasan dan subpokok bahasan perkuliahan PRTTI. Selain itu, pada kuesioner terdapat pula beberapa pertanyaan yang harus diisi respoden, yaitu

a. Pokok bahasan yang perlu ditambahkan?

b. Subpokok bahasa yang perlu ditambahkan?

c. Pokok bahasan yang perlu dihilangkan?

d. Subpokok bahasa yang perlu dihilangkan?

e. Masukan untuk perkuliahan PRTTI?

\section{HASIL DAN PEMBAHASAN}

Hasil penelitian ini berupa dua hal, yaitu CP Kurikulum Prodi TPPG yang sekait dengan mata kuliah PRTTI dan kebutuhan mahasiswa Prodi TPPG terhadap bahan ajar mata kuliah PRTTI. Pada dokumen kurikulum TPGG Tahun 2016, CP yang harus dikuasai mahasiswa Program Studi TPPG terdiri atas $10 \mathrm{CP}$ Sikap dan Tata Nilai, 10 CP Penguasaan Pengetahuan, 9 CP Keterampilan umum, dan 12 CP Keterampilan Khusus. Dari 41 CP Program Studi TPPG tersebut, terdapat enam $\mathrm{CP}$ yang sekait dengan perkuliahan PRTTI, yaitu:

a. Pada CP "Penguasaan Pengetahuan": Menguasai prinsip dan teknik berkomunikasi (lisan, tulisan, dan grafis).

b. Pada CP "Keterampilan umum": Mampu menyusun hasil kajian tersebut di atas dalam bentuk kertas kerja, spesifikasi desain, atau esai seni, dan mengunggahnya dalam laman perguruan tinggi dan mampu mendokumentasikan, menyimpan, mengamankan, dan menemukan kembali data untuk menjamin kesahihan dan mencegah plagiasi.

c. Pada CP "Keterampilan khusus": Mampu mengelola survei (merencanakan, mengimplementasikan, mengendalikan) dan interpretasi data (tata guna lahan, kontur, hidrologi), uji dan analisa kelaikan tanah (geoteknik), uji dan analisa material, untuk menghasilkan perancangan teknik bangunan gedung sesuai dengan norma-standar-pedoman dan manual; mampu menganalisis pekerjaan untuk menghasilkan laporan kemajuan pekerjaan (harian, mingguan dan bulanan); mampu membuat dokumen kontrak 7 sesuai syarat-syarat administrasi untuk tahap perencanaan, pelaksanaan dan pasca konstruksi.

Kebutuhan Mahasiswa Prodi TPPG terhadap bahan ajar mata kuliah PRTTI yang diperoleh melalui kuesioner adalah pokok bahasan dan subpokok bahasan bahan ajar mata kuliah PRTTI seperti yang tertera pada diagram berikut ini.

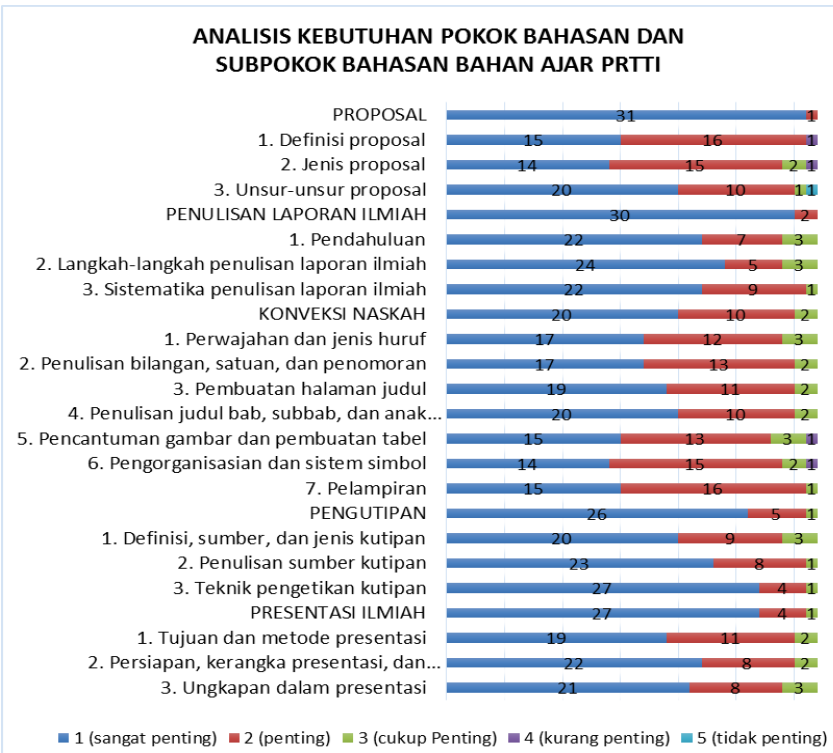

Gambar 2. Diagram Analisis Kebutuhan Pokok Bahasan dan Subpokok Bahasan PRTTI

Berdasarkan jawaban pada kuesioner terhadap pertanyaan-pertanyaan: (1) Pokok bahasan dan subpokok bahasan yang perlu ditambahkan? (2) Pokok bahasan dan subpokok bahasan yang perlu dihilangkan? diperoleh hasil 31 responden menuliskan tidak perlu ada tambahan terhadap pokok bahasan, sedangkan 1 responden mengajukan tambahan pokok bahasan "Evaluasi Laporan Ilmiah" dan pokok bahasan "Kalimat ilmiah" (yang dipelajari dalam mata kuliah Bahasa Indonesia) untuk diulang/dijadikan pokok bahasan pada mata kuliah PRTTI. Terhadap pertanyaan penghilangan pokok bahasan dan subpokok bahasan, 32 responden menuliskan tidak ada yang perlu dihilangkan.

\section{Pembahasan}

Pada gambar 2 diagram Analisis Kebutuhan Pokok Bahasan dan Subpokok Bahasan PRTTI, dapat dilihat Pokok bahasan Proposal, Penulisan Laporan Ilmiah, Konvensi Naskah, Pengutipan, dan Presentasi ilmiah dianggap sangat penting oleh responden. Hal ini terlihat dari presentase rerata pilihan responden terhadap semua pokok bahasan, yaitu $84.3 \%$ responden memilih opsi sangat penting $12,5 \%$ responden memilih opsi penting, dan $3,2 \%$ responden memilih opsi cukup penting; tidak terdapat responden yang memilih kurang penting dan tidak penting. Artinya, pokok-pokok bahasan tersebut menumbuhkan motivasi/minat mahasiswa, aktual, menarik (Prastowo, 2012) serta dapat difungsikan untuk mencapai keberhasilan sebuah proses belajar mengajar (Yuliyawati, 2016). Dengan demikian, Pokok bahasan Proposal, Penulisan Laporan Ilmiah, Konvensi Naskah, Pengutipan, dan Presentasi Ilmiah merupakan pokok bahasan kebutuhan mahasiswa pada Perkuliahan PRTTI.

Pada diagram tersebut, dapat pula dilihat presentase rerata pilihan responden terhadap semua subpokok bahasan dari setiap pokok bahasan. subpokok 
bahasan "Proposal" yang terdiri atas: Definisi Proposal, Jenis Proposal, Unsur-Unsur Proposal dianggap sangat penting responden atau merupakan subpokok bahasan bahan ajar kebutuhan mahasiswa karena presentase rerata semua subpokok bahasan tersebut adalah 51,3\% responden memilih opsi sangat penting; 42,6,5 \% responden memilih opsi penting, dan $3 \%$ responden memilih opsi cukup penting, 3\% responden memilih kurang penting dan $1 \%$ respondeng memilih tidak penting. Subpokok bahasan "Penulisan Laporan Ilmiah" yang terdiri atas: Pendahuluan, Langkah-langkah Penulisan Laporan Ilmiah, Sistematika Penulisan Laporan Ilmiah dianggap sangat penting oleh responden. Hal ini terlihat dari presentase rerata semua subpokok bahasan, yaitu $71 \%$ responden memilih opsi sangat penting $22 \%$ responden memilih opsi penting, dan $7 \%$ responden memilih opsi cukup penting, tidak terdapat responden memilih kurang penting dan tidak penting. Subpokok bahasan "Konvensi Naskah", yaitu: Perwajahan dan Jenis Huruf, Penulisan Bilangan, Satuan, dan Penomoran, Pembuatan Halaman Judul, Penulisan judul Bab, Subbab, dan anaksubbab, Pencantuman Gambar dan pembuatan Diagram, Pengorganisasian dan Sistem Simbol, dan Pelampiran, presentase rerata semua subpokok bahasannya adalah $52,7 \%$ responden memilih opsi sangat penting 40,2\% responden memilih opsi penting, dan $6,3 \%$ responden memilih opsi cukup penting, 0,8 responden memilih kurang penting dan tidak terdapat responden memilih tidak penting. Denga demikian, subpokok bahasan "Konvensi Naskah" merupakan subpokok bahasan bahan ajar kebutuhan mahasiswa.

Selain itu, Pada diagram tersebut, dapat dilihat subpokok bahasan "Pengutipan", yaitu: Definisi, Sumber, dan Jenis Kutipan, Penulisan Sumber Kutipan, Teknik Pengetikan Kutipan dianggap sangat penting atau merupakan subpokok bahasan bahan ajar kebutuhan mahasiswa. Hal ini terlihat dari presentase rerata semua subpokok bahasan, yaitu $76 \%$ responden memilih opsi sangat penting $20 \%$ responden memilih opsi penting, dan $4 \%$ responden memilih opsi cukup penting, tidak terdapat responden memilih kurang penting dan tidak penting. Subpokok bahasan "Presentasi Ilmiah yang terdiri atas: Tujuan dan Metode Presentasi, Persiapan, Kerangka dan Pelaksanaan Presentasi, dan Ungkapan dalam Presentasi, dianggap sangat penting atau merupakan subpokok bahasan bahan ajar kebutuhan mahasiswa. Hal ini terlihat dari presentase rerata pilihan responden, yaitu $71,2 \%$ responden memilih opsi sangat penting $24,8 \%$ responden memilih opsi penting, dan $4 \%$ responden memilih opsi cukup penting, tidak terdapat responden memilih kurang penting dan tidak penting.

Pada hasil penelitian ini diketahui tidak ada pokok bahasan dan subpokok bahasan yang perlu dihilangkan. Hal ini berarti bahwa pokok bahasan Proposal, Penulisan Laporan Ilmiah, konvensi Naskah, Plagiarisme dan Pengutipan, Peristilahan dan kalimat Ilmiah, dan Presentasi Ilmiah yang selama ini dipelajari pda perkuliahan PRTTI sudah merupakan pokok bahasan bahan ajar yang mahasiswa butuhkan. Hal ini dapat dijadikan satu di anatara usaha untuk meningkatkan prestasi belajar mahasiswa (Lestari 2013).

Hasil temuan kebutuhan mahasiswa akan pokok bahasan bahan ajar perkuliahan PRTTI yang terdiri atas Proposal, Penulisan Laporan Ilmiah, Konvensi Naskah, Pengutipan, dan Presentasi ilmiah telah memenuhi prinsip relevansi bahan ajar yang dikemukakan (Suhardiyanto 2018) bahwa materi pembelajaran hendaknya relevan atau ada keterkaitannya dengan CP. Pada CP "Penguasaan Pengetahuan", yaitu Menguasai prinsip dan teknik berkomunikasi (lisan, tulisan, dan grafis) dapat dicapai dengan memahami pokok bahasan "Penulisan Laporan Ilmiah dan Presentasi Ilmiah".

Pada CP "Keterampilan umum": Mampu menyusun hasil kajian tersebut di atas dalam bentuk kertas kerja, spesifikasi desain, atau esai seni, dan mengunggahnya dalam laman perguruan tinggi dan mampu mendokumentasikan, menyimpan, mengamankan, dan menemukan kembali data untuk menjamin kesahihan dan mencegah plagiasi dapat dicapai dengan memahami pokok bahasan "“Penulisan Laporan Ilmiah, Konvensi Naskah, serta Plagiarisme dan Pengutipan".

Pada CP "Keterampilan
mengelola $\quad \begin{gathered}\text { khusus": Mampu } \\ \text { (merencanakan, }\end{gathered}$
mengimplementasikan, mengendalikan) dan interpretasi data (tata guna lahan, kontur, hidrologi), uji dan analisa kelaikan tanah (geoteknik), uji dan analisa material, untuk menghasilkan perancangan teknik bangunan gedung sesuai dengan norma-standar-pedoman dan manual; mampu menganalisis pekerjaan untuk menghasilkan laporan kemajuan pekerjaan (harian, mingguan dan bulanan); mampu membuat dokumen kontrak7 sesuai syarat-syarat administrasi untuk tahap perencanaan, pelaksanaan dan pasca konstruksi. dapat dicapai dengan memahami pokok bahasan "Proposal dan Penulisan Laporan Ilmiah,”.

\section{SIMPULAN}

Hasil temuan kebutuhan mahasiswa akan pokok bahasan bahan ajar perkuliahan Proposal dan Tata Tulis Ilmiah telah memenuhi prinsip relevansi bahan ajar. Dengan demikian, dapat disimpulkan "keenam Capaian Pembelajaran" pada dokumen Kurikulum Program Studi Teknik perawatan dan Perbaikan Gedung, Politeknik Negeri Bandung dapat dicapai dengan pokok bahasan hasil analisis kebutuhan mahasiswa terhadap bahan ajar perkuliahan PRTTI, yaitu Proposal, Penulisan Laporan Ilmiah, konvensi Naskah, Plagiarisme dan Pengutipan, Peristilahan dan kalimat Ilmiah, dan Presentasi Ilmiah

\section{DAFTAR PUSTAKA}

Al-hamlan, S., \& Baniabdelrahman, A. A. (2015). "A Needs Analysis Approach to EFL Syllabus Development for Second Grade Students in Secondary Education in Saudi Arabia: A 
Descriptive Analytical Approach to Students Needs". American International Journal of Contemporary Research.

Alfiriani, A., Hutabri, E., \& Pratama, A. (2017). "Analisis Kebutuhan Belajar Mahasiswa Pada Mata Kuliah Strategi Pembelajaran TI." Pros. Seminar Pend. IPA Pascasarjana UM.

Andi, K., \& Arafah, B. (2017). "Using Needs Analysis to Develop English Teaching Materials in Initial Speaking Skills for Indonesian College Students of English." The Turkish Online Journal of Design, Art and Communication TOJDAC.

Helaluddin, H. (2018). "Analisis Kebutuhan dalam Redesain Silabus(RPS) Mata Kuliah Bahasa Indonesia di Perguruan Tinggi." Gramatika STKIP PGRI Sumatera Barat, 4(1). https://doi.org/10.22202/jg.2018.v4i1.2464

Irawati, H., \& Saifuddin, M. F. (2018). "Analisis Kebutuhan Pengembangan Bahan Ajar Mata Kuliah Pengantar Profesi Guru Biologi Di Pendidikan Biologi Universitas Ahmad Dahlan Yogyakarta." Bio - Pedagogi: Jurnal Pembelajaran Biologi.

Isgandhi, R. (2020). "Pembelajaran Bahasa Indonesia Kreatif sebagai Mata Kuliah Pengembangan Kepribadian pada Pendidikan Vokasi (Politeknik)." Pengembangan Humaniora, 15 No.3.

Kurniawan, W., Pujaningsih, F. B., Alrizal, A., \& Latifah, N. A. (2018). "Analisis Kebutuhan MahasiswaTerhadap Bahan Ajar Sebagai Acuan Untuk Pengembangan Modul Fisika Gelombang Bola dan Tabung." EduFisika. https://doi.org/10.22437/edufisika.v3i01.5805

Lestari, S. (2013). "Kajian Ragam Bahasa Slogan Pada Papan Reklame Di Kota Medan (Kajian Sosiolinguistik)." Sasindo.

Ndukwe, J. I. (2015). "Needs Analysis of an English for Academic Purpose (Eap) Programme: English Language Curriculum to the Effectiveness of the Primary School Teacher in Nigeria." IOSR Journal of Research \& Method in Education Ver. III. https://doi.org/10.9790/7388-05434547

Nurhayati. (2012). Silabus: Teori dan Aplikasi Pengembangannya. Leutikaprio.

Nurjannah, N. (2018). "Analisa Kebutuhan Sebagai Konsep Dasar dalam Pengembangan Kurikulum Bahasa Arab di MAN Curup." Arabiyatuna: Jurnal Bahasa Arab, 2(1), 49. https://doi.org/10.29240/jba.v2i1.409

Prastowo, A. (2012). Summary for Policymakers. In Intergovernmental Panel on Climate Change (Ed.), Climate Change 2013 - The Physical Science Basis (hal. 1-30). Cambridge University Press.

https://doi.org/10.1017/CBO9781107415324.004

Puspita, O. W., Andayani, Waluyo, H. J., \& Rohmadi, M. (2017). "A Needs Analysis for Poetry
Appreciation Textbooks in Universitites: An Exploratory Study." American Journal of Educational Research. https://doi.org/10.12691/education-5-4-3

Suhardiyanto, A. (2018). "Pengembangan Bahan Ajar Perencanaan Pembelajaran Ppkn Berbasis Student Centered Learning." Integralistik, $X X i X$.

Thamrin, M. (2014). "Pengembangan Bahan Ajar Penulisan Karya Ilmiah Berbasis Vokasi." LITERA. https://doi.org/10.21831/ltr.v13i1.1905

Yuliyawati, S. N. (2016). "Pengembangan Bahan Ajar Bahasa Indonesia Berbasis Kompetensi lulusan Bagi Program Studi Administrasi Bisnis Di Politeknik." Proceeding ASEAN Comparative Education Research Network Conference.

Yusuf, A. (2014). "Analisis Kebutuhan Pendidikan Masyarakat." Jurnal Penelitian Pendidikan. https://doi.org/10.15294/jpp.v31i2.5690 